\title{
Vaginal Smear and Neutrophil Count as an Alternative Method for Estrous Phase in Female Tiger (Panthera tigris sumatrae, Pocock, 1929)
}

\author{
Genoveva Kiranaputri ${ }^{1, *}$ Luthfiralda Sjahfirdi ${ }^{1}$ Ligaya ITA Tumbelaka ${ }^{2}$
}

\author{
${ }^{1}$ Department of Biology, Faculty of Mathematic and Natural Science, Universitas Indonesia \\ ${ }^{2}$ Department of Veterinary Clinic Reproduction and Pathology, Institut Pertanian Bogor \\ *Corresponding author. Email: genovv.k@gmail.com
}

\begin{abstract}
Detection of the estrous cycle is essential for basic reproductive aspects in all animals. Both natural mating and assisted reproductive techniques require estrous detection for breeding programs which will assist to maintain the tiger population in captivity. This research aims to explore alternative methods for tiger conservation in the remote area. Vaginal smear and neutrophil count were used to determine the phase of estrous cycle, and it easily applied on the field. Vaginal smears and blood smears were collected twice within interval 6 months $\mathrm{n}$ a female tiger at Tambling Wildlife Nature Conservation Rescue Centre. While tiger was restrained mechanically, blood samples were collected from the coccygeal vein and the vaginal smears were collected intravaginal. All procedure followed the animal welfare protocol. Vaginal smears were stained by $10 \% \mathrm{Giemsa}$. Basal/parabasal, intermediate, and superficial/cornified cells were identified to determine the reproductive periods under the microscope. Blood smears were stained by Giemsa-Wright. Neutrophils were counted within 200 white blood cells count under the microscope. The result showed that female tiger was in the follicular phase and neutrophil count was 78 cells at the $1^{\text {st }}$ sample collection. The $2^{\text {nd }}$ sample collection resulted in luteal phase with 55 neutrophils count. This research suggests vaginal smear and neutrophil count can be used as an alternative method of tiger estrous phase detection. In addition, these methods have economical and practical value.
\end{abstract}

Keywords: vaginal smears, neutrophil count, tiger, estrous, semi ex-situ

\section{INTRODUCTION}

Assisted reproductive technologies are being developed for wild cat conservation [1]. Artificial breeding technology and reproductive technology can contribute to species conservation [2]. Information of the basic reproductive aspects of wild mammals is scarce [3]. In vivo fertilization (IVF) successfully performed on tiger. However, effective and efficient basic research approach and applied reproductive biotechnology using mobile laboratory research are important for wildlife breeding programs [4]. This method widely used for companion animals [5], farm animals [6,7] and possible for wildlife animals $[8,9,10]$. The procedure can reliably be used for diagnosing phase of estrous and optimum time for mating [12].
Neutrophils often presence on vaginal smears observation $[13,14]$. Neutrophil infiltration into the vagina (female reproductive tract) is essential to maintaining the estrous cycle. Neutrophils maintain the estrous cycle through control of steroid hormone levels [15]. Both of immune response and proper structural integrity of the vagina require estrogen action in the vaginal epithelial cells [16]. Relationship between neutrophil blood count and neutrophil infiltration during the estrous cycle has been proven clinically by [17]. Neutrophils have crucial roles on female reproductive tract on the process of fertilization and immune response [18].

Tiger species is the second most researched species from Felidae family after the domestic cat [19]. Despite of those high frequency of researches, tiger's population is declining due to deforestation $[20,21,22,23,24]$, poaching $[25,26,27]$, and human- 
tiger conflict [28,29]. Estrous detection on the tiger leads to the optimum mating in breeding programs. Maintaining tiger's population is a part of tiger conservation. This research aims to explore alternative methods to detect the estrous phase on tiger species. By combining vaginal cytology and neutrophil blood count on the field, this research expects to minimize the risk of damaging the sample during transportation to the laboratory.

\section{MATERIALS AND METHODS}

\subsection{Subject}

This research was conducted in Tambling Wildlife Nature Conservation Rescue Centre (Tambling). The adult female tiger was translocated to the rescue centre on 2009 from Jambi because of human-tiger conflict. Tiger was given ad libitum water and live prey (10\% of body weight) twice a week. Tiger was conditioned in a solitary cage $(6 \mathrm{~m} \times$ $6 \mathrm{~m}$ ) and routinely moved to habitual cage in every 2 weeks. Individual cages were partly covered with roof adjusting for tropical condition. Tiger was freely choosing its position in the individual cage. Both cages had natural light setting. Animal husbandry and veterinary care were designed to follow animal welfare principle at Tambling Rescue Centre. This research was approved by the Ethics and Research Committee at the Faculty of Medicine Universitas Indonesia (Protocol Number 20-01-0058) and Secretariat of Scientific Authority for Biodiversity Indonesian Institute of Sciences (LIPI).

\subsection{Sample collection}

Vaginal smears and blood samples were taken from a female tiger twice during the sampling period. Samples collections were done within interval 6 months engaging the medical check-up routine by the Tambling's veterinarians. The samples collection could not be conducted on daily basis to minimize human-animal interaction at Tambling Rescue Centre. Tiger was restrained mechanically on a squeeze cage without anaesthesia. All procedures were conducted with safety consideration between the animal and the operators. All samples were collected lege artis and aseptically under 3 minutes (Figure 1).

Blood samples were drawn through lateral coccygeal vein aseptically. Sterile syringe $(3 \mathrm{ml})$ and needle $(22 \mathrm{G})$ were used to collect $0.5 \mathrm{ml}$ blood from the tiger. The needle was removed from the syringe. Blood smears were made as soon as possible after the

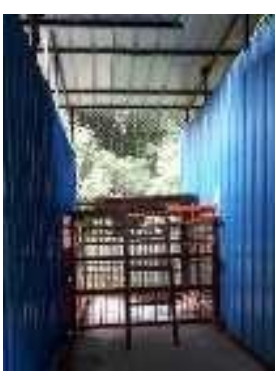

(a)

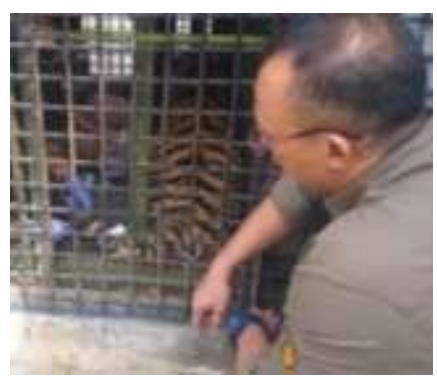

(b)
Figure 1. Sample collection on a female tiger with mechanical restraint. (a) cage designed ( $2 \mathrm{~m} \times 2 \mathrm{~m}$ and 1,5 $\mathrm{m}$ height) for mechanical restraint. (b) safety protocol between the tiger and the operators during sample collection.

blood collection. Clean object glass was given a drop of fresh blood from the syringe. Another object glass was put about $30^{\circ}$ to the drop of blood on the first object glass. The second object glass was pushed quickly and smoothly across the full-length after the blood spread within $2-3 \mathrm{~mm}$ of the first object glass [30,31]. The fixation of the blood smears was using methanol within $2-3$ minutes. Blood smears were stained after dried over fixation [32].

Vaginal smears were collected after the blood sampling. Sterile cotton swab slowly introduced about $4 \mathrm{~cm}$ into the vagina until reached the vaginal walls. Sterile cotton swab then gently rotated intravaginal and rolled onto a clean object glass [11]. Object glass was fixed by Bunsen lamp.

\subsection{Vaginal smears and blood smears staining}

Vaginal smears and blood smears staining were conducted in different area from the tiger's enclosure to minimize debris on the smears. The area for staining was conditioned to had a room temperature, avoid direct sunlight and rainy or windy weather. Vaginal smears were stained with $10 \%$ Giemsa for 15 minutes $[10,33,34]$. Blood smears staining were used combination of Giemsa-Wright solution. Blood smears were dipped into Wright solution for 2 minutes then rinsed with aquadest solution. Blood smears were dipped into $10 \%$ Giemsa solution for 15 minutes [35]. Vaginal smears and blood smears were rinsed by aquadest solution after staining. 


\subsection{Vaginal smears and blood smears analysis}

All analysis of the smears under the microscope were conducted after the slides dried. Identification of the cells on vaginal smears was done through microscope at $40 x$ and 200x magnification. Basal/parabasal, intermediate, and superficial/cornified cells were observed to determine the cycle of estrous cycle [10,33]. Type of cells on the smear were evaluated as traces $(+/-)$; none $(-)$, little $(+)$, medium $(++)$, or dense $(+++)[13,14]$.

Neutrophil blood count was conducted through microscope at $40 x$ and $400 x$ magnification. Neutrophils were counted within 200 cells of white blood cells count (differential leucocyte) under the microscope $[31,36,37]$. Neutrophil blood count is higher on follicular/ovulatory phase than luteal phase. Lower neutrophils count on the blood are resulted from the neutrophil translocation to the female reproductive tract. Following [17] and [18] hypothesis, neutrophil blood counts were added to determine the cycle of oestrus cycle with vaginal smear method. Mobile phone camera that put to the ocular lens of the microscope were used to document all photos in this research.

\section{RESULT AND DISCUSSION}

\subsection{Vaginal smears examination}

Epithelial cells from the vagina were observed under the microscope using sterile cotton swab technique. The results from the present study showed basal/parabasal, intermediate, and superficial/cornified cells were observed on the vaginal smears. Considering this research was conducted on a female tiger as a wild animal without anaesthesia, rapid and practical sampling techniques were required. Cotton swab technique for vaginal smear was chosen for this research. Cotton swab technique is successfully applied to cheetah [38] and African lion [11]. Cell identifications from vaginal smears in this research showed similar result to the previous researches [11,14,39,40,41].

From the vaginal smear observations, first smears indicated the female tiger was on follicular phase at the oestrous cycle. Intermediate $(++)$ and superficial/cornified cells (+++) were dominant on the vaginal smears (Figure 2). Second vaginal smears indicated luteal phase on the estrous cycle. Basal (+), parabasal (++), and intermediate cells (+++) (Figure 3) were dominant on the second vaginal smears collection. Type of cell densities of the vaginal smears on this research were suitable to previous studies [13,14]. The total population of the cells on the smears in domestic cat are changing at the $1^{\text {st }}-4^{\text {th }}$ day of follicular phase according to other researchers $[43,44]$. Specifically, Cornified cells increase from

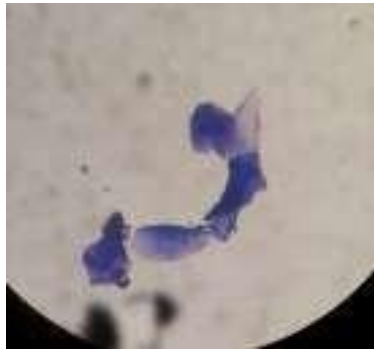

(a)

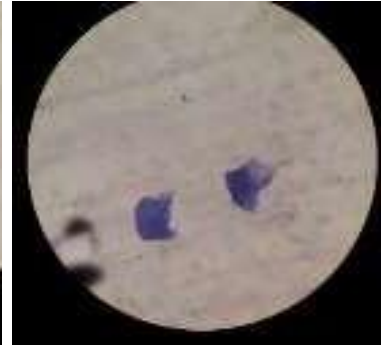

(b)

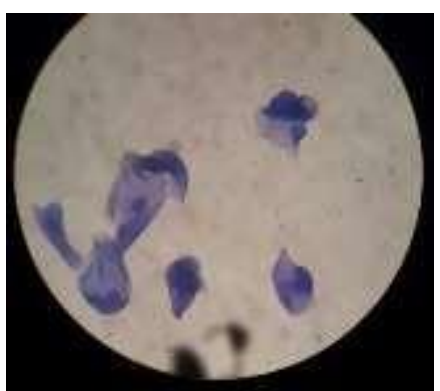

(c)

Figure 2. Documentation of first vaginal smears. Slides were dominated by cornified/superficial $(a, b)$ and intermediate cells (c) at 40× magnification (personal documentation by handphone Samsung ${ }^{\circledR}$ A5 camera).

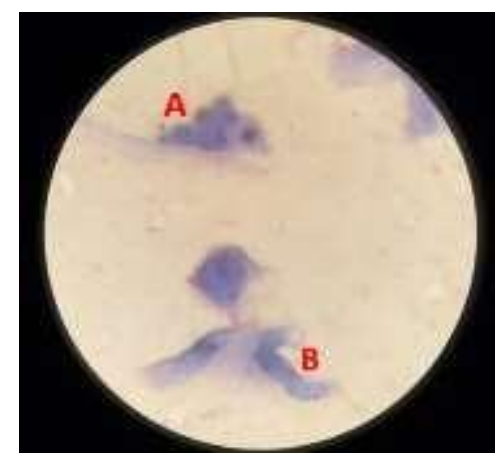

Figure 3. Documentation of second vaginal smears. Slides were dominated by basal cells and parabasal cells (A) and intermediate cells (B) at 400x magnification (personal documentation by handphone Samsung ${ }^{\circledR}$ A5 camera).

$5 \%$ to $40 \%$ of total cell population and intermediate cells decrease progressively from $45 \%$ to $6 \%$. At the $4^{\text {th }}-7^{\text {th }}$ day of follicular phase while superficial cells 
stay at range from $40 \%$ - 50\%. Parabasal cells are not found in the smears during follicular phase. Parabasal cells generally low through the cycle, $1 \%-6 \%$ according to [42] or $<10 \%$ according to [45] from total population of the cells on the smears. The explanation from previous research [42] are the follicular phase is defined as the period of time when the estradiol-17 $\beta$ concentrations in plasma exceeded $20 \mathrm{pg} / \mathrm{ml}$ from the base levels $(11.7 \mathrm{pg} / \mathrm{ml})$. The mean length of the follicular phase is around 7.4 days and ranged from $3-16$ days.

This present study showed there was no neutrophil (-) infiltration on vaginal smears. In this case, it could be happened due to minimum time during sample collection. All sample collection had to be done under $<3$ minutes to minimize the stress of the tiger. Neutrophils are observed on vaginal smears in other literatures $(13,14,39,40)$. According to previous studies, neutrophil densities increase from little (+) to medium (++) at the onset of proestrus (13). Neutrophils may be seen in the first few days of proestrous but cannot be found in the middle of proestrous (41). Few neutrophils (+) presence at the late proestrous. At estrous period, neutrophils begin to reappear. Neutrophils are dense $(+++)$ at metestrus of the estrous cycle. Neutrophils begin to present in low densities during anoestrous [13,39,43]. Neutrophils are observed in vaginal epithelial tissue at every period confirmed by histological evidence [44]. Neutrophils are relatively delicate cells and can easily rupture during sample collection or processing vaginal smears [14]. Neutrophils may lost of sight during vaginal smears observation under the microscope.

Luteal phase and follicular phase of the female tiger could be determined on this present study. However, contact or interaction between human and tiger should be minimized on this research to sustain the tiger's wild behaviour. Sample collection was performed twice in this research. Sample collections on daily basis for future researches were recommended to detect estrous cycle (proestrous, estrous, metestrous, and anestrous).

Variety length of estrous cycle has been reported in other literature by $[46,47,48,49]$. The usual oestrous cycle length of Bengal tiger is 25 days based upon behaviour observations and hormonal data [47]. The longest estrous cycle length of Sumatran tiger is $58.3 \pm 2.7$ days based on fecal progesterone $(\mathrm{P} 4)$ and sexual behaviour observations in Japan has been reported by [48].

The female Sumatran tiger at Tambling Rescue Centre showed different phase within 6 months of interval. Contrary to [47] findings, Siberian tiger has anestrous period (which is luteal phase) up to 8 months period of time. Based on the usual estrous cycle length (25 days), this research predicted the tiger had passed 7 estrous cycles.

This female tiger habitat was conditioned in tropical season. Both cages (solitary cage and habitual cage) were designed partly covered so the tiger could access freely to direct sunlight or sheltered from the sunlight. The individual cage was covered by the roof and the habitual cage was covered with natural trees. From the earlier researches, tiger's estrous cycle and breeding season are synchronized by photoperiod [47,48,49,50]. Tiger's reproduction is seasonal as well as clouded leopard, Palla's cat and snow leopard species. Other felids species such as fishing cats, pumas, ocelots, margays, leopards and captive lions are not influenced by season [48]. Estrous cycles of the female Felidae are highly variable. The estrous cycle of female felids may be influenced by seasonality factor, dietary factor, housing, and captivity-related stress [49].

$\mathrm{P}_{4}$ and estrogen hormones have been recorded for reproductive analysis on animals $[47,49]$. Hormonal assays have its own challenges. Results from hormonal assays may be influenced by degradative activity of the bacteria on the feces that affect to the $\mathrm{P}_{4}$ metabolites, transportation condition, sample storage, extraction method, sensitivity and specificity of the assays [50]. Vaginal smears are fine aid in the diagnosis of the period of estrous cycle in many species and reflects the effect of estrogenprogesterone hormones interaction on the female reproductive tracts [12]. Vaginal smear method remains as a proper method or the gold standard method in life animals than others verified method to detect estrous cycle [41].

\subsection{Combining neutrophil blood counts with vaginal smears examination}

The first neutrophil blood count (Figure 4) resulted 78 cells on first collection and 55 cells on the second collection. Elaborated with medical check- up result on the female tiger by the veterinarian team, the tiger was on a healthy condition with no clinical symptoms. There is a minor difference compared to other literatures. Other literatures show neutrophil values ranged from 57 - 75 cells on wild ranging Bengal tiger with anaesthesia [51]. Female captive tiger has neutrophil values ranged $63.58 \pm 0.48$ cells without any anaesthesia [52]. Anaesthesia not only has anaesthetic and analgesia effects but also 
immunomodulatory effects. Neutrophils as innate and adaptive immunity agents [53,54] are affected by ketamine [55]. Ketamine supresses neutrophil chemotaxis (neutrophil migrations) leads to immunosuppression effect $[55,56]$.

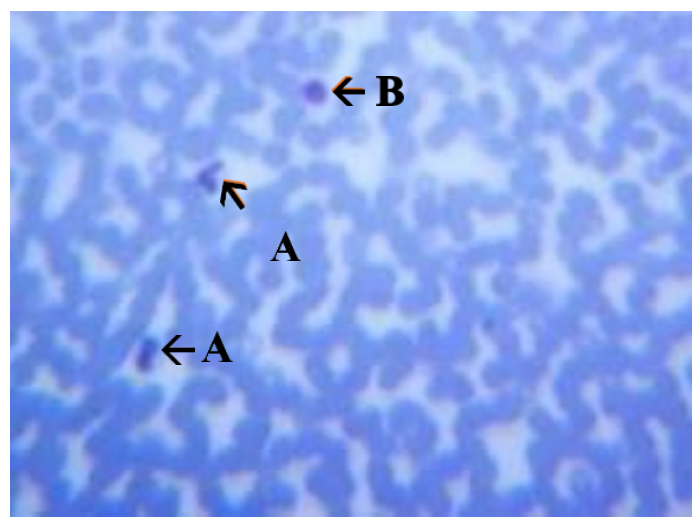

Figure 4. Neutrophil blood count. (A) Neutrophils with segmented nuclei and (B) lymphocyte on blood smears at 400x magnification (personal documentation by handphone Samsung ${ }^{\circledR}$ A5 camera).

Both [51] and [52] researches, the tiger bloods are added to anticoagulant agent on sample collection. A possible explanation is both neutrophil values from those literature were using EDTA. Blood smears were fixed using methanol directly after the blood collection in this research. Time storage of anticoagulant EDTA on blood sampling effects the blood count. Prolonged storage of peripheral blood cell in EDTA produces various artefacts. Neutrophil percentage decreases between 1 hour, 4, 8, \&12 hours storage at the room temperature $(57,58)$. Low leucocyte counts due to leucocyte aggregation induced by EDTA has been reported by $(59,60)$. Neutrophil count with citrate coagulation shows 6,26 $\times 10^{9} / \mathrm{L}$, while EDTA coagulant shows $4,8 \times 10^{9} / \mathrm{L}$ (60).

Neutrophil blood count was higher on the $1^{\text {st }}$ sample than the $2^{\text {nd }}$ sample. Other researcher [17] provides evidence by immunohistochemical data of neutrophil counts in the blood were significantly high at day one (or $1^{\text {st }}$ day) compared to $2^{\text {nd }}$ day of the estrous cycle. Their findings suggest there is possibility the neutrophils from the blood translocate to the female reproductive tract (FRT) such as endometrium on $2^{\text {nd }}$ day of the estrous cycle. Another research [18] supports those statements by reviewing (1) the contribution of sex hormones in regulating the functionality of neutrophils, (2) the contribution of neutrophils during fertilization process, pregnancy process and, controlling infectious diseases (caused by viral/fungal/bacterial). Lower numbers of neutrophils on FRT are observed at ovulatory/follicular phase. Increased numbers of neutrophils on FRT are observed at post-ovulatory phase. Cyclic steroid sex hormones regulate the permeability of the FRT and then allowing neutrophil to access into FRT.

Neutrophils number decline in the vaginal lumen during the follicular phase of estrous cycle. Neutrophils in the vaginal lumen are characterized by the elevated estradiol $\left(\mathrm{E}_{2}\right)$ levels, and then disappear at the onset maximum peak of $\mathrm{E}_{2}$ level of the ovulatory phase, and finally neutrophils elevate again during the luteal phase. $\mathrm{P}_{4}$ levels are at peak during the luteal phase of estrous cycle. High level of $\mathrm{E}_{2}$ level throughout the ovulation period may inhibit neutrophil-mediated immunity. $\mathrm{E}_{2}$ and $\mathrm{P}_{4}$ affect epithelial cells [61,62]. The cyclical wave (physiological regulation) of neutrophil's number in the vaginal lumen migration is initiated by chemokines [61,62] and correlated with circulating $\mathrm{E}_{2}$ hormone levels [44].

Brown (2006) [48] summarized endocrinology of nondomestic felids. Female cycles in general are within $2-4$ weeks interval with estrous period lasting from 3 - 10 days. Estrogen's surges from fecal sample collection can distinguish estrous period from intrerestrous period in female reproductive cycle. In the other hand, pregnancy diagnosis based on $\mathrm{P}_{4}$ hormone level analysis during the $1^{\text {st }}$ half of gestation period is not possible due to indistinguishable hormone level to the luteal phase profiles. Technically it possible to diagnose gestation or pregnancy if the $\mathrm{P}_{4}$ is still elevated after 40 days post-copulation $[47,63]$. P4, testosterone, and, androstenedione hormone metabolites are significantly increased on the gestation period compared to the lactation period on the female tiger [64].

In this present research, neutrophil blood counts were integrated with vaginal smears examination to complement the detection of estrous cycle. Neutrophil blood count was higher ( 77 cells) when the vaginal smears were dominated by intermediate and superficial cells. Contrast to the $1^{\text {st }}$ sampling, neutrophil blood count was lower (55 cells) when the vaginal smears were dominated by basal and intermediate cells on the $2^{\text {nd }}$ sampling. It indicated that neutrophil on the blood was higher during follicular phase and lower during luteal phase. This research aligned with previous research [17].

Neutrophils play important role in both innate and adaptive immunity. Neutrophils are the $1^{\text {st }}$ type of 
leucocytes to arrive at affected tissues and as a microbicidal agent [53,54]. The presence of neutrophils at FRT are to aid the breakdown of endometrial tissue of FRT with elastase and to elevate the innate immunity defense mechanism as the epithelial barrier is disrupted. Commensal organisms, growth factors and sex hormones contribute to regulate cells of the innate and adaptive immune systems against potential pathogens. Regulation of immune systems (innate and adaptive immunity) protects the FRT [65].

During at the end of ovulatory phase, estrogen reduces the membrane permeability of the FRT. Then the migration of neutrophil to the FRT decreases to permit sperm survival and mobility in the FRT. It leads in increased risk of infection [18]. Medication from $\mathrm{E}_{2}$-based or deregulation of $\mathrm{P}_{4}$ expression may compromise the vaginal immunity and making FRT more vulnerable to pathogens [66].

\subsection{Detecting Breeding Time to Maintain Tiger Population}

This research showed vaginal smears using cotton swab can be applicated on big cats such as tiger. Consistent to (11) and (67) studies, this method was effective under field conditions. Neutrophil blood count could be a complementary method on the vaginal examination to identify estrous phase. Behavioural observation may be collaborated with vaginal smears and neutrophil blood count method in the future researches.

Vaginal smears collection and evaluation/assessment techniques required practice and proper training. Previous research [14] mentioned those training is easily mastered. This research also suggests to practice vaginal smears collection, blood sampling, and evaluation at the laboratory before performing those techniques in the remote setting/area. Proper training and practice lead to consistent and reliable data.

Information of optimum time for breeding might be useful for maintaining tiger population. The female tiger on this research had history of mating with free- ranging male tiger on the Tambling Rescue Centre and successfully delivered tiger cubs in 2012. Both natural mating and ARTs required estrous detection for breeding programs. Estrous detection for breeding is already popular on pet animals $[5,43]$ and farm animals [6,7]. Maintaining tiger's population through breeding programs is a part of conservation efforts.
Reproductive knowledge of basic biology to advance biotechnologies in Felidae have been continually researched and studied for conservation. The zoos have an important contribution in the felid conservation by assisted reproductive biotechnology (ARTs) protocols to create ex-situ breeding and management programs. In the long run, ex-situ conservation also provides knowledge to sustain genetic diversity and then finally sustain the population of endangered felid species [68]. Reproductive aspects on wild female tiger have been reported by [69] and gene flow by [70]. Both of exsitu and in-situ conservation must collaborate to maintain biodiversity conservation $[71,72]$.

\section{CONCLUSION}

Vaginal smears and neutrophil blood count can be an alternative method to determine estrous phase beside hormonal assays. Neutrophil blood count can act as a complement to vaginal smear method in detecting estrous phase. Neutrophil blood count is higher during follicular phase. In the contrary, neutrophil blood count is lower during luteal phase. This research shows that it is possible to perform those methods on a tiger, especially in the remote area.

\section{ACKNOWLEDGMENT}

We would like to express our appreciation to Tambling Wildlife Nature Conservation, Balai Konservasi Sumber Daya Alam \& Lembaga Ilmu Pengetahuan Indonesia for supporting this research.

\section{REFERENCES}

[1] J. Kochan, W. Niżański, N. Moreira, Z.C. da Silva, A. Nowak, S. Prochowska, A. Partyka, W. Mlodawska, J. Skotnicki, ARTs in wild felid conservation programmes in Poland and in the world, Journal of Veterinary Research 63(3) (2019) 457-464, doi: 10.2478/jvetres-20190043.

[2] W.V. Holt, Cryobiology, wildlife conservation \& reality, CryoLetters 29(1) (2008) 43-52.

[3] A.R Silva, N. Moreira, A.F. Pereira, G.C.X. Peixoto, K.M. Maia, L.B. Campos, A.A. Borges, Estrus cycle monitoring in wild mammals: challenges and perspectives, IntechOpen, 2017, pp.21-45. Available from: https://www.intechopen.com/books/theriogenol ogy/estrus-cycle-monitoring-in-wild-mammalschallenges-and-perspectives 
[4] A.M. Donoghue, L.A. Johnston, U.S. Seal, D.L. Armstrong, R.L. Tilson, P. Wolf, K. Petrini, L.G. Simmons, T. Gross, D.E. Wildt, In vitro fertilization and embryo development in vitro and in vivo in the tiger (Panthera tigris), Biology of Reproduction 43 (1990) 733-744.

[5] A.L. Antono, Application of exfoliative vaginal cytology in clinical case canine reproduction-A review, Bulgarian Journal of Veterinary Medicine 20(3) (2017) 193-203, doi: 10.15547/bjvm.997.

[6] K. Miroud, D.E. Noakes, Exfoliative vaginal cytology during the oestrus cycle of the cow, after ovariectomy, and after exogenous progesterone and oestradiol-17 $\beta$, British Veterinary Journal 146(5) (1990) 387-397.

[7] B.F. Zohara, Azizumnesa, Md.F. Islam, Md.G.S. Alam, F.Y. Bari, Exfoliative vaginal cytology and serum progesterone during the estrous cycle of indigenous ewes in Bangladesh, Journal of Embryo Transfer 29(2) (2014) 183188, doi: http://dx.doi.org/10.12750/JET.2014. 29.2.188.

[8] G.B. Stenson, Oestrus and the vaginal smear cycle of the river otter, Lutra canadensis, Journals of Reproduction \& Fertility 83 (1988) 605-610.

[9] R. Aaziz, F. Vorimore, H. Verheyden, D. Picot, C. Bertin, A. Ruettger, K. Sachse, and K. Laroucau, Detection of atypical Chlamydiaceae in roe deer (Capreoulus capreoulus), Veterinary Microbiology 181 (2015) 318-322, doi: http://dx.doi.org/10.1016/j.vetmic.201 5.10.018.

[10] A. Mayasari, A. Suryawan, M. Christita, A.T.J. Simamora, A. Abinawanto, Suryanda, and A. Bowolaksono, Vaginal swab cytology application to determine the estrus cycle of lowland anoa (Bubalus depressicornis, Smith, 1927) in captivity, MATEC Web of Conference $197 \quad$ (2018) 1-5, doi: http://doi.org/10.1051/matecconf/20 1819706008 .

[11] Callealta, A. Ganswindt, I. Lueders, Reproductive cycle stage assessment using vaginal cytology evaluation in African lions (Panthera leo). Animal Reproduction Science 213 (2020) 106-260.

[12] M. Sharma, N. Sharma, Vaginal cytology: an historical perspective on its diagnostic use,
Advances in Animal and Veterinary Sciences 4(6) (2016) 283-288.

doi:http://dx.doi.org/10.14737/journal.a avs/2016/4.6.283.288.

[13] T. Bekyürek, N. Liman, and G. Bayram, Diagnosis of sexual cycle by means of vaginal smear method in the chinchilla (Chinchilla laniger), Laboratory Animals 36 (2002) 51-60.

[14] M. Cora, L. Kooistra, and G. Travlos, Vaginal cytology of the laboratory rat and mouse: Review and criteria for staging of the estrous cycle using stained vaginal smears, Toxicology Pathology 43 (2015) 776-793, doi: $10.1177 / 0192623315570339$.

[15] S. Sasaki, K. Nagata, and Y. Kobayashi, Regulation of the estrous cycle by neutrophil infiltration into the vagina, Biochemical and Biophysical Research Communications 382 (2009) 35-40, doi:10.1016/j.bbrc.2009.02.112.

[16] S. Li, G.G. Herrera, K.K. Tam, J.S. Lizarraga, M-T. Beedle, W. Winuthayanon. Estrogen action in the epithelial cells of the mouse vagina regulates neutrophil infiltration and vaginal tissue integrity, Scientific Reports 8 (2018) 112-147, doi:10.1038/s41598-018-29423-5

[17] M. Steffl, L. Telgen, M. Schweiger, W.M. Amselgruber, Estrous cycle-dependent activity of neutrophils in the porcine endometrium: Possible involvement of the heat shock protein 27 and lactoferrin, Animal Reproduction Science $121 \quad$ (2010) 159-166, doi:10.1016/j.anireprosci.2010.05.018.

[18] S. Hahn, P. Hasler, L. Vokalova, S.V. van Breda, O. Lapaire, N.G. Than, I. Hoesli, S.W. Rossi, The role of neutrophil activation in determining the outcome of pregnancy and modulation by hormones and/or cytokines, Clinical and Experimental Immunology 198 (2019) 24-36, doi: 10.1111/cei.13278.

[19] L.A. Stanton, M.S. Sullivan, and J.M. Fazio, A standardized ethogram for Felidae: A tool of behavioral researchers, Applied Animal Behaviour Science 173 (2015) 3-16.

[20] M.F. Kinnaird, E.W. Sanderson, T.G. O'Brien, H.T. Wibisono, G. Woolmer, Deforestation trends in a tropical landscape and implications for endangered large mammals, Conservation Biology 17(1) (2003) 245-257. 
[21] M. Linkie, S. Christie, The value of wild tiger conservation, Oryx 41(4) (2007) 415-416.

[22] R.A. Joshi, E. Dinerstein, E. Wikramanayake, M.L. Anderson, D. Olson, B.S. Jones, J. Seidensticker, S. Lumpkin, M.C. Hansen, N.C. Sizer, C.L. Davis, P. Palminteri, N.R. Hahn, tracking changes and preventing loss in critical tiger habitat, Sci Adv 2(4) (2016) e1501675.

[23] M.S. Luskin, W.R. Albert, M.W. Tobler, Sumatran tiger survival threatened by deforestation despite increasing densities in parks, Nat Com 8 (1783) (2017) 1-9.

[24] E.E. Poor, Y. Shao, M.J. Kelly, Mapping and predicting forest loss in Sumatran tiger landscape from 2002 to 2050, Jour of Environmental Management 231 (2019) 397404.

[25] M. Linkie, G. Chapron, D.J. Martyr, J. Holden, N. Leader-Williams, Assessing the viability of tiger subpopulations in a fragmented landscape, Journal of Applied Ecology 43 (2006) 576-586.

[26] F. Rifae, J. Sugardjito, Y.L. Fitriana, Spatial point pattern analysis of the Sumatran tiger (Panthera tigris sumatrae) poaching cases in and around Kerinci Seblat National Park, Sumatera, Biodiversitas 16(2) (2015) 331-319.

[27] D. Risdianto, D.J. Martyr, R.T. Nugraha, A. Harihar, H.T. Wibisono, D.W. MacDonald, N. D'Cruze, M. Linkie, Examining the shifting patterns of poaching from a long-term law enforcement intervention in Sumatra, Biology Conservation 204 (2016) 306-312

[28] P.J Nyhus, R. Tilson R, Characterizing HumanTiger Conflict in Sumatera, Indonesia: Implications for Conservation, Oryx 38(1) (2004) 68-74

[29] M.I. Lubis, W. Pusparini, S.A. Prabowo, W. Marthy, Tarmizi, N. Andayani, M. Linkie, Unraveling the complexity of human-tiger conflicts in the Leuser Ecosystem, Sumatra,Animal Conservation, 2020; doi:10.1111/acv.12591, $1-9$.

[30] A.H. Rebar, P.S. MacWilliams, B.F. Feldman, F.L. Metzger, R.V.H. Pollock, and J. Roche, A guide guide hematology in dogs and cats, USA: Tenton NewMedia, 2001, pp.11-12, 70-82, 105-107.
[31] H. Theml, H. Diem, T. Haferlach, Color Atlas of Hematology: Practical Microscopic and Clinical Diagnosis, United Stated: Thieme New York, 14 (2004) 17-9.

[32] S. Bakhri, Analisis jumlah leukosit dan jenis leukosit individu yang tidur dengan lampu menyala dan yang dipadamkan, Jurnal Media Analisis Kesehatan 1(1) (2018) 83-91. [In Bahasa Indonesia]

[33] R. Bowen, Cytologic changes through the canine estrous cycle, 1998. Available from: http://www.vivo.colostate.edu/hbooks/pathphys/ reprod/vc/cycle.html.

[34] T.N. Siregar, J. Melia, C.N. Rohaya, D. Thasmi, S. Maysita, J. Wahyuni, Rosa, B Nurhafni, Panjaitan, Herrialfian, Determining proportion of exfoliative vaginal cell during various stages of estrous cycle using vaginal cytology techniques in Aceh Cattle. Veterinary Medicine International 2016, Article ID: 1976125.

[35] R. Ardina, S. Roslinda, Morfologi eosinophil pada apusan darah tepi menggunakan pewarnaan giemsa, wright, dan kombinasi wright-giemsa Jurnal Surya Medika 3(2) (2018) 5-12. [In Bahasa Indonesia]

[36] M.G. Kerr, Veterinary Laboratory Medicine: Clinical Biochemistry and Haematology $2^{\text {nd }}$ Edition, Australia: Blackwell Publishing, 2002, pp. 49-65.

[37] A.B. Shrivastav, K.P. Singh, Tigers Blood: Haematological and Biochemical Studies, Blood Cell - An Overview of Studies in Haematology, Terry E. Moschandreou, IntechOpen, 2012. doi: $10.5722 / 50360$.

[38] C.S. Asa, R.E. Junge, J.S. Bircher, G.A. Noble, K.J. Sarri, E.D. Plotka, Assessing reproductive cycles and pregnancy in cheetahs (Acinonyx jubatus) by vaginal cytology, Zoo Biology 1(3) (1992) $139 \quad-\quad 151$, doi:10.1002/zoo14301100303.

[39] J.N. Mills, V. Valli, J. Lumsden, Cyclical changes of vaginal cytology in the cat, The Canadian Veterinary Journal 20 (1979) 95-101.

[40] Aydin, E. Sur, T. Ozadin, D.A. Dinc, Determining of the stages of the sexual cycle of the bitch by direct examination, Journal of Animal and Veterinary Advances 10(15) (2011) 1962-1967. 
[41] A.F. Ajayi, R.E. Akhigbe, Staging estrous cycle and induction of estrous experimental rodents: an update, Fertility Research and Practice 6(1) (2020) 1-15, doi: https://doi.org/10.1186/s40738- 020-00074-3.

[42] V.M. Shille, K.E. Lundström, G.H. Stabenfeldt, Follicular function in the domestic cat as determined by estradiol-17 concentrations in plasma: relation to estrous behaviour and cornification of exfoliated vaginal epithelium, Biology of Reproduction 21 (1979) 953-963.

[43] A.P. Pertiwi, L.I.T.A. Tumbelaka, M.F. Ulum, Ultrasonographic and vaginal cytological diagnostic of the queen, Indonesian Journal of Animal and Veterinary Sciences 23(3) (2018) 130-142, doi: http://dx.doi.org/10.14334/jitv.v23i3. 1809.

[44] S. Li, G.G. Herrera, K.K. Tam, J.S. Lizarraga, M-T. Beedle, W. Winuthayanon, Estrogen action in the epithelial cells of the mous vagina regulates neutrophil infiltration and vaginal tissue integrity, Scientific Reports 8(1) (2018) doi: 10.1038/s41598-018-29423-5.

[45] H. Kanca, K. Karakas, S. Salar, H. Izgur, Vaginal cytology after induction of ovulation of the queen: comparison of postoestrus and dioestrus, The Journal of the Australian Veterinary Journal 92(3) (2014) 65-70.

[46] R.M.F.S. Sadleir, Notes on reproduction in the larger Felidae, International Zoo Yearbook 6(1) (1966) 184-187. doi: 10.1111/j.17481090.1966.tb01746.x

[47] U. Seal, E.D. Plotka, J.D. Smith, F.H. Wright, N.J. Reindl, R.S. Taylor, and M.F. Seal, Immunoreactive luteinizing hormone, estradiol, progesterone, testosterone, and androstenedione levels during the breeding season and anestrus in Siberian tigers, Biology of Reproduction 32 (1985) 361-368.

[48] J.L. Brown, Comparative endocrinology of domestic and nondomestic felids, Theriogenelogy $66 \quad$ (2006) 25-36, doi:10.1016/j.theriogenology.2006.03.011

[49] H.D. Putranto, S. Kusuda, T. Ito, M. Terada, K. Inagaki, O. Doi, Reproductive cyclicity based on fecal steroid hormones and behaviors in Sumatran Tigers, Panthera tigris sumatrae, Japanese Journal of Zoo and Wildlife Medicine 12(2) (2007)111-115.
[50] C.J. Andrews, D.G. Thomas, J. Yapura, M.A. Potter, Reproductive biology of the 28 extant felid species: A review, Mammal Review 49 (2018) 16-30, doi: 10.1111/mam.12145.

[51] I.D. Peter, A.W. Haron, F.F.A. Jesse, M. Ajat, M.H.W. Han, W.N. Fitri, M.S. Yahaya, M.S.M. Alamaary, Opportunities and challenges associated with fecal progesterone metabolite analysis. Veterinary World 11(10) (2018) 14661472.

[52] A.B. Shrivatav, K.P. Singh, S.K. Mittal, P.K. Malik, Haematological and biochemical studies in tigers (Panthera tigris tigris), European Journal of Wildlife Research 58 (2011) 365 367.

[53] B. Allwin, P.A. Kalaignan, S. Kanniappan, S. Vairamuthu, and Jayathangaraj, Hematological and serum biochemical indices of captive Royal Bengal Tigers (Panthera tigris), Arignar Anna Zoological Park, Vandaloor, Chennai. Indian Journal of Animal Research 2019. doi: 10.18805/ijar.B-3718.

[54] A. Mantovani, M.A. Cassatella, C. Costantini, and S. Jaillon, Neutrophils in the activation and regulation of innate and adaptive immunity. Nature Reviews Immunology 11(8) (2011) 519531. doi:10.1038/nri3024.

[55] B. Rosales, Neutrophils at the crossroads of innate and adaptive immunity, Journal of Leucocyte Biology (2020) 1-20, doi:10.1002/JLB.4MIR0220-574RR.

[56] S.L. Anderson, T. Duke-Novakovski, B. Singh, The immune response to anesthesia: Part 2 sedative opioids, and injectable anesthetic agents. Veterinary Anaesthesia and Analgesia 41(6) (2014) 553-556, doi:10.1111/vaa.12191.

[57] F-L. Liu, T-L. Chen, R-M. Chen, Mechanisms of ketamine- induced immunosuppression. Acta Anaesthesiologica Tawainica 50(4) (2012)172177, doi:10.1016/j.aat.2012.12.001.

[58] B.H. Chen, J.F. Fong, C.H. Chiang, Effect of different anticoagulant, underfilling of blood sample and storage stability on selected hemogram, Kaohsiung J Med Sci 15(2) (1999) 87-93.

[59] R. Thakur, O.P. Moorjani, Time effect storage artifacts of anticoagulant EDTA on peripheral blood cells. Journal of Medical Science and Clinical Research 3(5) (2015) 5728-5733. 
[60] G. Banfi, G.L. Salvagno, G. Lippi, The role of ethylenediamine tetraacetic acid (EDTA) as in vitro anticoagulant for diagnostic purposes. Clinical Chemical Laboratory Medicine 45(5) (2007) 565-576.

[61] S.M. Al-Amoudi, Anticoagulant induced leucoagglutination, Saudi Medical Journal 39(8) (2008) 1192-1193.

[62] Y. Sonoda, N. Mukaida, J-B. Wang, M. Shimada-Hiratsuka, M. Naito, T. Kasahara, A. Harada, M. Inoue, and K. Matsushima, Physiologic regulation of postovulatory neutrophil migration into vagina in mice by a CX-C chemokine(s), The Journal of Immunology 160 (1998) 6159-6165.

[63] C.R. Wira, M. Rodriguez-Garcia, M.V. Patel, The role of sex hormones in immune protection of the female reproductive tract. Nature Reviews Immunology 15 (2015) 217-230.

[64] A. Thongphakdee, W. Tipkantha, C. Punkong, and K. Chatdarong, Monitoring and controlling ovarian activity in wild felids. Theriogenelogy 2018. doi: $\quad 10.106 / j$.theriogenelogy. 2017.12.010

[65] S. Mandol, R.K. Booth, and S.K. Wasser, Fecal stress, nutrition and reproductive hormones for monitoring environmental impacts on tigers (Panthera tigris), Conservation Physiology 8(1) (2020) coz091. doi:10.1093/conphys/conz093.

[66] D.K. Hickey, M.V. Patel, J.V. Fahey, C.R. Wira, Innate and adaptive immunity at mucosal surfaces of the female reproductive tract: stratification and integration of immune protection against the transmission of sexually transmitted infections, Journal of Reproductive Immunology 88 (2011) 185-194.

[67] S. Lasarte, R. Samaniego, L. Salinas-Muñoz, M.A. Guia-Gonzalez, L.A. Weiss, E. Mercader, E. Ceballos-Garcia, Novarro-González, L. Moreno-Onchoa, F. Perez-Millan, M. Pion, P. Sanchez-Mateos, A. Hidalgo, M.A. MuñozFernandez, and M. Relloso, Sex hormones coordinate neutrophil immunity in the vagina by controlling chemokine gradients, Journal of Infectious Diseases Advances Access. 2015. doi: 10.1093/infdis/jiv402

[68] I.M. Vela-Vargas, L. Pérez-Pabón, P. Larraín, andJ. Pérez-Torres, Vaginal smears: A key source information on the estrous cycle of neotropical bats, Mastozoología Neotropical 23(1) (2016) 139-145.

[69] A. Thongphakdee, W. Sukparangsi, P. Comizzoli, K. Chatdarong, Reproductive biology and biotechnologies in wild felids. Theriogenology 150 (2020) 360-373.

[70] R. Singh, Q. Qureshi, K. Sankar, P.R. Krausman, S.P. Goyal, Reproductive characteristics of female Bengal tigers, in Ranthambhore Tiger Reserve, India, European Journal of Wildlife Research 60 (2014) 579587, doi: 10.1007/s10344-014-0822-3.

[71] P.W. Hendrick, S. Singh, and J. Aspi, Estimation of male gene floe: use caution, Journal of Heredity (2015) 745-748. doi:10.1093/jhered/esv082.

[72] R.M.S. Price, Zoos as a force for conservation: A simple ambition - but how? Oryx 39 (2005) 109-110.

[73] K.R. Schwartz, E.C.M. Parsons, L. Rockwood, and T.C. Wood, Integrating in-situ and ex-situ data management processes for biodiversity conservation. Frontiers in Ecology and Evolution 5(120) (2017) 1-7. 